\title{
THE ASSOCIATION BETWEEN RETINOL-BINDING PROTEIN 4 AND CARDIOVASCULAR RISK SCORE IS MEDIATED BY WAIST CIRCUMFERENCE IN OVERWEIGHT/OBESE ADOLESCENT GIRLS
}

\author{
Aleksandra Klisić1 ${ }^{1}$ Nebojša Kavarić ${ }^{1}$, Bojko Bjelaković2 Ivan Soldatović3 \\ Milica Martinović ${ }^{4}$ and Jelena Kotur-Stevuljevićs
}

\begin{abstract}
${ }^{1}$ Primary Health Care Center, Podgorica, Montenegro; ${ }^{2}$ Clinical Department of Pediatrics, School of Medicine, University of Niš, Niš; ${ }^{3}$ Institute for Biostatistics, Medical Informatics and Research in Medicine, School of Medicine, University of Belgrade, Belgrade, Serbia; ${ }^{4}$ Department for Pathophysiology and Laboratory Medicine, School of Medicine, University of Montenegro, Podgorica, Montenegro; ${ }^{5}$ Department of Medical Biochemistry, School of Pharmacy, University of Belgrade, Belgrade, Serbia
\end{abstract}

SUMMARY - Retinol-binding protein 4 (RBP4) is an emerging risk factor for atherosclerotic disease in adults. However, to our knowledge, there are no studies examining the relationship between RBP4 and cardiovascular risk in young population. Therefore, we aimed to estimate this potential relationship in overweight/obese adolescent girls. Seventy overweight/obese adolescent girls, mean age $17.6 \pm 1.20$ years, were included. Anthropometric and biochemical parameters were measured. Cardiovascular risk score (CVRS) was calculated by adding points for each risk factor (e.g., sex, high-density lipoprotein cholesterol (HDL-c), non-HDL-c, smoking, blood pressure and fasting glycemia). According to the risk status, we divided adolescent girls into low, medium and high risk groups ( $-2 \leq \mathrm{CVRS} \leq 1,2 \leq \mathrm{CVRS} \leq 4$ and CVRS $\geq 5$, respectively). We found significantly higher RBP4 in the high risk group as compared with low risk group $(\mathrm{p}<0.001)$. However, multiple linear regression analysis showed waist circumference (beta $=0.257, \mathrm{p}=0.031$ ) to be the only independent predictor of higher cardiovascular risk (adjusted $\mathrm{R}^{2}=0.342, \mathrm{p}<0.001$ ). In conclusion, $\mathrm{RBP} 4$ may be associated with higher cardiovascular risk in overweight/obese adolescent girls, but this association is mediated by abdominal obesity.

Key words: Adolescents; Cardiovascular diseases; Risk; Obesity; Retinol-binding protein 4

\section{Introduction}

Due to the growing proportion of children and adolescents affected by obesity, identifying those at an increased risk of developing cardiovascular $(\mathrm{CV})$ and metabolic complications later in life is of paramount importance ${ }^{1}$. In addition, there is a critical need for novel biomarkers to best assess, predict and treat chil-

Correspondence to: Aleksandra Klisić, $M D$, PhD, Primary Health Care Center, Trg Nikole Kovačevića 6, 81000 Podgorica, Montenegro

E-mail: aleksandranklisic@gmail.com

Received September 1, 2016, accepted December 13, 2016 dren that are prone to develop cardiovascular disease $(\mathrm{CVD})^{2}$. Epidemiological data in Montenegro from 2008 reported that $21.2 \%$ of children and adolescents aged 7-19 years were overweight or obese ${ }^{3}$, whereas in 2015 the prevalence of childhood overweight and obesity was $22.9 \%$ and $5.3 \%$, respectively ${ }^{4}$.

Obesity is characterized by changes in adipocytokines, activation of low-grade inflammation and increased production of reactive oxygen species, leading to metabolic disorders, insulin resistance (IR), and $\mathrm{CVD}^{5,6}$.

Retinol-binding protein (RBP4) is a recently discovered adipokine that is involved in IR development ${ }^{7}$. 
IR was found to be accompanied by down-regulation of the insulin responsive glucose transporter-4 (GLUT4), which might be a signal for RBP4 secretion from adipocytes and development of systemic $\mathrm{IR}^{8}$. Moreover, RBP4 has been recently proposed as an emerging risk factor of atherosclerotic disease in adults $^{9,10}$.

It is well established that insulin resistance and compensatory hyperinsulinemia are the main risk factors of CVD, eventually leading to plaque formation and development of atherosclerosis, through which the prominent role of RBP4 as a modulator of atherosclerosis in hyperinsulinemia may be explained ${ }^{11}$.

To our knowledge, there are no studies examining the relationship between RBP4 and cardiovascular risk in young obese population, having in mind that the effect of obesity on CVD risk often tracks from childhood and adolescence, even if manifest heart disease rarely presents before adulthood ${ }^{12}$. Concerning the growing proportion of pediatric population affected by obesity in Montenegro, we aimed to examine this potential relationship in a cohort of overweight/obese, otherwise healthy adolescent girls.

\section{Subjects and Methods}

\section{Study population}

The study included 70 randomly selected overweight/obese adolescent girls (mean age 17.6 \pm 1.20 years) who volunteered to participate in the study. Participants were selected from several secondary schools in Podgorica and were recruited in the Primary Health Care Center on their regular check-up in the period from December 2012 to March 2013. All the participants completed a questionnaire including demographic characteristics, somatic illnesses, medication use, and lifestyle habits. Medical history and clinical examinations were carried out on the same day. In addition, all participants with fasting glucose $\geq 5.6$ $\mathrm{mmol} / \mathrm{L}$ but $\leq 6.9 \mathrm{mmol} / \mathrm{L}$ underwent a two-hour oral glucose tolerance test (OGTT) with $75 \mathrm{~g}$ anhydrous glucose dissolved in $250 \mathrm{~mL}$ of water in order to exclude diabetes ${ }^{13}$.

Inclusion criteria were overweight and obese, otherwise healthy adolescent girls aged 16-19 years. Girls younger than 16 years and older than 19 years, as well as girls with diabetes mellitus or fasting glucose $\geq 7.0$ $\mathrm{mmol} / \mathrm{L}$ were excluded from the study. There were no participants with 2-hour postload glucose $\geq 11.1$ $\mathrm{mmol} / \mathrm{L}$ to be excluded from the study ${ }^{13}$. Furthermore, girls with renal dysfunction, hepatic dysfunction, thyroid dysfunction, cardiovascular disorders, signs and symptoms of acute inflammatory disease, history of alcohol consumption and smoking, and those using any medications were also excluded from the study. Girls were instructed not to perform any vigorous physical activity on the day before the blood was drawn. All the participants provided their written informed consent, and for those younger than 18 years the parents' written approval was obtained. The study protocol was approved by the Ethics Committee of the Primary Health Care Center in Podgorica and the research was carried out in compliance with the Declaration of Helsinki ${ }^{14}$.

\section{Anthropometric measurements}

Basic anthropometric measurements including body height $(\mathrm{cm})$, body weight $(\mathrm{kg})$ and waist circumference (WC, $\mathrm{cm}$ ) were obtained in the morning. Weight was measured to the nearest $0.1 \mathrm{~kg}$ on a balance beam scale, with the subjects barefoot and with light clothing. Height was measured to the nearest $0.1 \mathrm{~cm}$ using a wall-mounted stadiometer, without shoes. WC was measured with the non-stretchable tape, over unclothed abdomen at the midpoint between the lowest rib and the iliac crest, and at the end of normal expiration. The tape was parallel to the floor and did not compress the skin. Body mass index (BMI) was calculated as weight in kilograms divided by height in square meters $\left(\mathrm{kg} / \mathrm{m}^{2}\right)$. BMI z-score was also calculated. Using the World Health Organization (WHO) growth reference 5-19 years ${ }^{15}$, adolescent girls were categorized as overweight $(+1 \mathrm{SD}<\mathrm{BMI} \mathrm{z}$-score $<+2 \mathrm{SD}$ ) or obese (with BMI z-score $\geq+2 \mathrm{SD}$ ). Normal-weight girls $(-2 \mathrm{SD} \leq \mathrm{BMI} z$-score $\leq+1 \mathrm{SD})$ were excluded from the study. Blood pressure was measured with a sphygmomanometer. Average of three measurements taken on the right arm was recorded. All measurements were taken by the same trained evaluator.

The risk of CVD was estimated using modified risk score for identifying young individuals with a high probability of having advanced atherosclerotic lesions, reported by McMahan et al. ${ }^{16}$. Cardiovascular risk score (CVRS) was calculated by adding points for each risk factor (e.g., female sex, high-density lipoprotein cholesterol (HDL-c), non-HDL-c, smoking, blood 
pressure and fasting glycemia), as described previous$1 y^{17}$. Hypertension was defined as systolic blood pressure (SBP) or diastolic blood pressure (DBP) $\geq 130 / 85$ $\mathrm{mm} \mathrm{Hg}$, and hyperglycemia was defined as fasting glucose $\geq 5.6 \mathrm{mmol} / \mathrm{L}^{18}$.

\section{Biochemical analyses}

Blood samples were obtained between 7.00 and 9.00 a.m., after 12- to 14 -hour overnight fast. Samples were left to clot for 30 minutes and then centrifuged at $3000 \mathrm{rpm}$ for 10 minutes. Serum levels of glucose, total cholesterol, HDL-c, low density lipoprotein cholesterol (LDL-c), and triglycerides (TG) were measured using standardized enzymatic procedures, spectrophotometrically (Roche Cobas 400, Mannheim, Germany). Serum RBP4 levels were determined using a nephelometric assay (Behring Nephelometer Analyzer, Marburg, Germany). Insulin was measured by chemiluminescent immunometric assay (AxSYM, Abbott, Abbott Park, IL, USA). Homeostasis model assessment of insulin resistance (HOMA-IR) was calculated: HOMA-IR = fasting glucose $(\mathrm{mmol} / \mathrm{L}) \mathrm{x}$ fasting insulin $(\mu \mathrm{IU} / \mathrm{L}) / 22.5^{19}$.

\section{Statistical analysis}

Statistical analysis was performed using SPSS statistical package (version 15.0 for Windows, SPSS, Chicago, IL, USA). Data are presented as mean \pm standard deviation, median (interquartile range), or counts and percentages. Differences between groups were evaluated with Student's t-test for normally and Mann-Whitney test for non-normally distributed parameters, or oneway ANOVA and Kruskal-Wallis nonparametric analysis of variance where appropriate. Spearman's nonparametric correlation analysis was used to determine the relationships between CVRS and other variables. Multiple linear regression analysis (MLR) was performed to identify independent factors affecting CVRS and to estimate the final predictors of its variability. Due to skewed distribution, log transformed HOMA-IR and triglycerides were used. In all analyses, $\mathrm{p}$ value of $<0.05$ was considered statistically significant.

\section{Results}

Table 1 shows general clinical and biochemical characteristics of the study overweight/obese participants.
Table 1. General characteristics of overweight/obese adolescent girls studied

\begin{tabular}{|l|l|}
\hline Characteristic & $\begin{array}{l}\text { Overweight/obese girls } \\
(\mathrm{n}=70)\end{array}$ \\
\hline Age (years) & $17.6 \pm 1.20$ \\
$\mathrm{BMI}\left(\mathrm{kg} / \mathrm{m}^{2}\right)$ & $28.3 \pm 3.02$ \\
$\mathrm{BMI}$ z-score & $1.45 \pm 0.33$ \\
WC $(\mathrm{cm})$ & $92.4 \pm 12.77$ \\
Fasting glucose $(\mathrm{mmol} / \mathrm{L})$ & $5.18 \pm 0.37$ \\
Fasting insulin $(\mu \mathrm{IU} / \mathrm{L})$ & $8.25(3.90-12.20)$ \\
HOMA-IR & $1.89(0.92-2.87)$ \\
TC $(\mathrm{mmol} / \mathrm{L})$ & $4.27 \pm 0.66$ \\
HDL-c $(\mathrm{mmol} / \mathrm{L})$ & $1.39 \pm 0.39$ \\
LDL-c $(\mathrm{mmol} / \mathrm{L})$ & $2.45 \pm 0.55$ \\
TG $(\mathrm{mmol} / \mathrm{L})$ & $0.88(0.64-1.23)$ \\
Non-HDL-c (mmol/L) & $2.88 \pm 0.67$ \\
TG/HDL-c ratio & $0.63(0.42-1.10)$ \\
SBP $(\mathrm{mm} \mathrm{Hg})$ & $112 \pm 18.1$ \\
DBP $(\mathrm{mm} \mathrm{Hg})$ & $73.4 \pm 11.38$ \\
RBP4 (mg/L) & $33.6 \pm 6.65$ \\
Cardiovascular risk score & $1.00(-1.00-4.00)$ \\
\hline
\end{tabular}

Data are presented as mean \pm standard deviation or median (interquartile range) $\mathrm{BMI}=$ body mass index; $\mathrm{WC}=$ waist circumference; HOMA-IR = homeostasis model assessment of insulin resistance; $\mathrm{TC}=$ total cholesterol; HDL-c $=$ high density lipoprotein cholesterol; LDL-c = low density lipoprotein cholesterol; TG = triglycerides; $\mathrm{SBP}=$ systolic blood pressure; $\mathrm{DBP}=$ diastolic blood pressure; $\mathrm{RBP} 4$ = retinol-binding protein 4

In the current study, we aimed to test the association of cardiometabolic parameters with the risk of CVD (as estimated using the modified risk score). Therefore, we calculated this cardiovascular risk score (CVRS) for every overweight/obese adolescent girl included in the study and, regarding their risk status level, we divided them into low, medium and high risk groups $(-2 \leq$ risk score $\leq 1,2 \leq$ risk score $\leq 4$ and risk score $\geq 5$, respectively). We found significant difference in several metabolic parameters independent of risk score calculation, i.e., significantly higher TG $(\mathrm{p}<0.001)$, insulin $(\mathrm{p}=0.007)$ and HOMA-IR ( $\mathrm{p}=0.001$ ), as well as anthropometric parameters (e.g., BMI, BMI z-score and WC) in the high risk group as compared with the low risk group $(\mathrm{p}=0.001, \mathrm{p}=0.002$ and $\mathrm{p}<0.001$, respectively). In addition, the RBP4 level was found to increase with the increasing cardiovascular risk score $(p<0.001)$. These results are shown in Table 2. 
Table 2. Cardiometabolic parameters in subgroups according to cardiovascular risk level

\begin{tabular}{|c|c|c|c|c|}
\hline Parameter & $\begin{array}{l}\text { Low risk score } \\
(-2 \leq \mathrm{CVRS} \leq 1), \\
\mathrm{n}=45\end{array}$ & $\begin{array}{l}\text { Medium risk score } \\
(2 \leq \mathrm{CVRS} \leq 4), \\
\mathrm{n}=11\end{array}$ & $\begin{array}{l}\text { High risk score } \\
(C V R S \geq 5), \\
n=14\end{array}$ & $\mathrm{p}^{*}$ \\
\hline Age (years) & $17.6 \pm 1.12$ & $17.4 \pm 1.36$ & $17.7 \pm 1.38$ & 0.772 \\
\hline $\mathrm{BMI}\left(\mathrm{kg} / \mathrm{m}^{2}\right)$ & $27.4 \pm 2.50^{\mathrm{aa}, \mathrm{bb}}$ & $30.3 \pm 3.42$ & $29.9 \pm 3.00$ & 0.001 \\
\hline BMI z-score & $1.34 \pm 0.27^{\mathrm{aa}, \mathrm{bb}}$ & $1.65 \pm 0.37$ & $1.62 \pm 0.36$ & 0.002 \\
\hline $\mathrm{WC}(\mathrm{cm})$ & $88.4 \pm 11.34^{\mathrm{aa}, \mathrm{bb}}$ & $99.2 \pm 11.01$ & $99.9 \pm 13.40$ & $<0.001$ \\
\hline Glucose $(\mathrm{mmol} / \mathrm{L})$ & $4.99 \pm 0.29^{\text {aаa,bbb }}$ & $5.53 \pm 0.22$ & $5.49 \pm 0.29$ & $<0.001$ \\
\hline $\mathrm{TC}(\mathrm{mmol} / \mathrm{L})$ & $4.21 \pm 0.63$ & $4.42 \pm 0.54$ & $4.35 \pm 0.84$ & 0.580 \\
\hline HDL-c $(\mathrm{mmol} / \mathrm{L})$ & $1.52 \pm 0.41^{\text {aaa,bb }}$ & $1.18 \pm 0.20$ & $1.14 \pm 0.18$ & $<0.001$ \\
\hline LDL-c (mmol/L) & $2.34 \pm 0.51$ & $2.62 \pm 0.51$ & $2.64 \pm 0.65$ & 0.101 \\
\hline $\mathrm{TG}(\mathrm{mmol} / \mathrm{L})^{\#}$ & $0.69(0.59-0.92)^{\mathrm{aa}, \mathrm{bb}}$ & $1.24(1.03-1.67)$ & $0.99(0.86-1.39)$ & $<0.001$ \\
\hline $\begin{array}{l}\text { Non-HDL-c }(\mathrm{mmol} / \mathrm{L}) \\
\text { TG/HDL-c ratio }\end{array}$ & $\begin{array}{l}2.69 \pm 0.58^{\text {aa,bb }} \\
0.56(0.32-0.73)^{\text {aаa, }, \mathrm{bbb}}\end{array}$ & $\begin{array}{l}3.24 \pm 0.57 \\
1.14(0.75-1.44)\end{array}$ & $\begin{array}{l}3.21 \pm 0.78 \\
0.78(0.72-1.24)\end{array}$ & $\begin{array}{l}0.005 \\
<0.001\end{array}$ \\
\hline Insulin $(\mu \mathrm{IU} / / \mathrm{L})^{\#}$ & $6.70(3.67-9.07)^{\text {ааа }}$ & $8.30(3.92-13.60)$ & $12.20(8.60-19.60)$ & 0.007 \\
\hline HOMA-IR ${ }^{\#}$ & $1.51(0.90-2.08)^{\text {ааа }}$ & $2.03(0.95-3.51)^{\mathrm{aa}}$ & $3.09(2.10-5.06)$ & 0.001 \\
\hline $\mathrm{SBP}(\mathrm{mm} \mathrm{Hg})$ & $103 \pm 13.1^{\text {aaa,bbb }}$ & $122 \pm 14.7$ & $132 \pm 14.0$ & $<0.001$ \\
\hline $\mathrm{DBP}(\mathrm{mm} \mathrm{Hg})$ & $68.5 \pm 8.57^{\text {aаa,b }}$ & $76.4 \pm 10.74^{a}$ & $86.4 \pm 8.86$ & $<0.001$ \\
\hline $\mathrm{RBP} 4(\mathrm{mg} / \mathrm{L})$ & $31.3 \pm 5.71^{\mathrm{aa}, \mathrm{bb}}$ & $37.8 \pm 7.81$ & $37.4 \pm 5.36$ & $<0.001$ \\
\hline
\end{tabular}

${ }^{\mathrm{a}} \mathrm{p}<0.05,{ }^{\text {aa }} \mathrm{p}<0.01,{ }^{\text {aaa }} \mathrm{p}<0.001$ vs. high risk score; ${ }^{\mathrm{b}} \mathrm{p}<0.05,{ }^{\mathrm{bb}} \mathrm{p}<0.01,{ }^{\mathrm{bbb}} \mathrm{p}<0.001$ vs. medium risk score; ${ }^{\#}$ data with non-gaussian distribution are shown as median values (interquartile range); " $p$ value from one-way ANOVA or Kruskal-Wallis nonparametric analysis of variance, followed by nonparametric Mann-Whitney U test, where appropriate; CVRS = cardiovascular risk score; BMI = body mass index; WC = waist circumference; HOMA-IR = homeostasis model assessment of insulin resistance; TC = total cholesterol; HDL-c $=$ high density lipoprotein cholesterol; LDL-c = low density lipoprotein cholesterol; $\mathrm{TG}=$ triglycerides; $\mathrm{SBP}=$ systolic blood pressure; $\mathrm{DBP}=$ diastolic blood pressure; RBP4 = retinol-binding protein 4

Table 3. Spearman's correlation coefficients $(\rho)$ of cardiovascular risk score with study parameters independent of risk score calculation in overweight/obese adolescent girls

\begin{tabular}{|l|l|l|}
\hline Variable & $\rho$ & $\mathrm{p}$ \\
\hline Age $($ years $)$ & 0.042 & 0.727 \\
BMI $\left(\mathrm{kg} / \mathrm{m}^{2}\right)$ & 0.422 & $<0.001$ \\
BMI z-score & 0.375 & 0.002 \\
WC $(\mathrm{cm})$ & 0.494 & $<0.001$ \\
Insulin $(\mu \mathrm{IU} / \mathrm{L})$ & 0.418 & $<0.001$ \\
HOMA-IR & 0.471 & $<0.001$ \\
TC $(\mathrm{mmol} / \mathrm{L})$ & 0.124 & 0.303 \\
LDL-c $(\mathrm{mmol} / \mathrm{L})$ & 0.360 & 0.003 \\
TG $(\mathrm{mmol} / \mathrm{L})$ & 0.555 & $<0.001$ \\
RBP4 $(\mathrm{mg} / \mathrm{L})$ & 0.441 & $<0.001$ \\
\hline
\end{tabular}

$\mathrm{BMI}=$ body mass index; $\mathrm{WC}=$ waist circumference; HOMA-IR = homeostasis model assessment of insulin resistance; $\mathrm{TC}=$ total cholesterol; LDL-c = low density lipoprotein cholesterol; TG = triglycerides; $\mathrm{SBP}=$ systolic blood pressure DBP $=$ diastolic blood pressure; $\mathrm{RBP} 4$ = retinol-binding protein 4
Table 4. Multiple regression analysis with cardiovascular risk score as dependent variable $\left(R^{2}=0.342, p<0.001\right)$

\begin{tabular}{|l|l|l|l|}
\hline Independent variable & $\mathrm{B}$ & Std. $\beta$ & $\mathrm{p}$ \\
\hline WC & 0.070 & 0.257 & 0.031 \\
tTG & 0.344 & 0.195 & 0.124 \\
tHOMA-IR & 1.758 & 0.175 & 0.132 \\
RBP4 & 0.079 & 0.152 & 0.226 \\
\hline
\end{tabular}

$\mathrm{WC}=$ waist circumference; $\mathrm{tTG}=$ logarithmically transformed triglycerides; tHOMA-IR = logarithmically transformed homeostasis model assessment of insulin resistance; RBP4 = retinol-binding protein 4

Thereafter, we performed Spearman's nonparametric correlation to examine the potential relationship between cardiovascular risk score and cardiometabolic parameters independent of risk score calculation. As shown, CVRS correlated positively with BMI z-score $(\mathrm{p}=0.002)$, BMI and WC $(\mathrm{p}<0.001$ both $)$, LDL-c $(\mathrm{p}=0.003), \mathrm{TG}(\mathrm{p}<0.001)$, insulin and HOMA-IR 
( $\mathrm{p}<0.001$ both), as well as with RBP4 level ( $\mathrm{p}<0.001)$. No significant correlations of CVRS with age and total cholesterol level were observed (Table 3).

Multiple linear regression (MLR) analysis was performed to identify which of the measured markers showed highest association with CVRS. Namely, all variables found to have a significant predictive value in Spearman's nonparametric correlation (e.g., WC, HOMA-IR, TG, RBP4), were further analyzed in MLR analysis for CVRS prediction. After MLR, WC (beta $=0.257$; $\mathrm{p}=0.031$ ) was the only independent predictor of high cardiovascular risk. These results are shown in Table 4. Adjusted $\mathrm{R}^{2}$ for the best model was 0.342 , which means that $34.2 \%$ of variation in CVRS could be explained with this model.

\section{Discussion}

The risk of CVD later in life in apparently healthy children can be assessed by clustering individual risk factors in the same individual, thus describing status with several of these risk factors being high at the same time $^{20}$. Obesity is one of the main risk factors associated with increased CVD risk in children and adolescents $^{17}$. In the current study, the risk of CVD was estimated using modified risk score, as described previously ${ }^{17}$ for identifying young individuals with a high probability of having advanced atherosclerotic lesions, reported by McMahan et al. ${ }^{16}$.

We have previously reported on the relationship between cardiovascular risk score and several established CV risk factors (e.g., ALT activity, hsCRP level, TG/HDL-c ratio, and bilirubin concentrations) in the group of adolescent girls ${ }^{17}$. However, there is a critical need for research in order to identify more biomarkers to best assess, predict and treat children that are prone to develop CVD. To our knowledge, the relationship between CVRS and RBP4 is a novel finding in the current study, considering that there are no studies examining the relationship between RBP4 and cardiovascular risk in young population. However, this association is mediated by abdominal obesity as measured by WC.

Studies in adult population have shown that RBP4 is an emerging risk factor of atherosclerotic disease ${ }^{9,10}$. Feng et al. ${ }^{21}$ showed that RBP4 correlated positively with carotid atherosclerosis in patients with type 2 diabetes mellitus and could be used as an early predic- tor of CVD. Higher circulating RBP4 concentrations were also observed in subjects with high-grade carotid stenosis, inflammatory dilated cardiomyopathy, coronary artery disease and advanced heart failure as compared with control subjects ${ }^{9}$. Even though RBP4 has been proposed as an emerging cardiometabolic risk factor in adults ${ }^{10,22}$, there are discrepancies regarding some of the possible metabolic roles of RBP4 in children and adolescents ${ }^{23-26}$.

During 3-year follow up, changes in RBP4 in children indicated that increases were associated with worsening IR, independently of $\mathrm{BMI}^{23}$. Goodman et al. ${ }^{27}$ provided longitudinal data on the role of RBP4 in modulating IR and suggested that the change in IR in non-Hispanic black adolescents was related to RBP4 and was dependent on the initial RBP4 level.

It is well established that IR and compensatory hyperinsulinemia are the main risk factors of $\mathrm{CVD}^{11}$. Insulin is a highly potent cell growth factor, which can promote vascular smooth muscle cell proliferation, thus playing an important role in the development of atherosclerosis $^{28}$. Since RBP4 is related to IR, it has been suggested to be involved in the occurrence and development of atherosclerosis and $\mathrm{CVD}^{11}$.

On the other hand, other studies did not find significant differences in RBP4 concentrations between patients with coronary artery disease and healthy individuals ${ }^{29,30}$. In addition, in a prospective six-year study in about 1000 patients with CVD, Mallat et al. ${ }^{31}$ found the risk of CVD to have increased with increasing RBP4 level. However, after adjustment for confounding factors, positive correlation between the RBP4 level and the risk of CVD disappeared, thus suggesting that RBP4 may not be a good predictor of CVD.

In our study, RBP4 level increased in parallel with increasing cardiovascular risk score. However, our results suggest that the association between RBP4 and cardiovascular risk is not independent but that abdominal obesity may be the underlying determinant of this relationship. Our results are in line with previous studies, which suggest that RBP4 is primarily associated with adipose tissue mass ${ }^{7}$.

Limitations of the present study must be considered. Due to its cross-sectional design, the causal relationship between biochemical and anthropometric parameters and cardiovascular risk could not be established. It should also be noted that the small number 
of participants was a limitation for a study dealing with cardiovascular risk assessment. However, the findings of the present study supported the hypothesis that higher serum RBP4 could in part reflect a higher cardiovascular risk even in young overweight/obese population.

\section{Conclusion}

High serum RBP4 levels were associated with higher cardiovascular risk in overweight/obese adolescent girls, but this association was dependent on abdominal obesity, as measured by WC. Prospective studies and further analyses are needed to clarify the potential role of RBP4 in adverse cardiovascular outcomes. Better understanding of its role in CVD risk prediction in the adolescent population may lead to discovery of a new target therapy for young individuals at highest risk of malignant sequels of obesity later in life.

\section{Acknowledgment}

This work was supported in part by a grant from the Ministry of Education, Science and Technological Development, Republic of Serbia (Project number OI 175035-J. Kotur-Stevuljević).

\section{References}

1. DeBoer MD. Obesity, systemic inflammation, and increased risk for cardiovascular disease and diabetes among adolescents: a need for screening tools to target interventions. Nutrition. 2013;29:379-86. doi: 10.1016/j.nut.2012.07.003

2. Canas JA, Sweeten S, Balagopal PB. Biomarkers for cardiovascular risk in children. Curr Opin Cardiol. 2013;28(2):103-14. doi: 10.1097/HCO.0b013e32835dd0ce

3. Ministarstvo zdravlja Crne Gore, Akcioni plan za ishranu i bezbjednost hrane Crne Gore, 2010-2014, Podgorica 2010 (Ministry of Health of Montenegro, Action plan for nutrition and food safety of Montenegro, 2010-2014, Podgorica 2010).

4. Martinovic M, Belojevic G, Evans G, Lausevic D, Asanin B, Samardzic M, et al. Prevalence of and contributing factors for overweight and obesity among Montenegrin schoolchildren. Eur J Public Health. 2015;25(5):833-9. doi: 10.1093/eurpub/ ckv071

5. Martinac M, Pehar D, Karlović D, Babić D, Marčinko D, Jakovljević M. Metabolic syndrome, activity of the hypothalamic-pituitary-adrenal axis and inflammatory mediators in depressive disorder. Acta Clin Croat. 2014;53:55-71. PMID: 24974667
6. Rakočević L, Rakočević V. Incidence of cardiovascular risk factors in obese children. Acta Clin Croat. 2016;55:407-13. doi: 10.20471/acc.2016.55.03.09

7. Friebe D, Neef M, Erbs S, Dittrich K, Kratzsch J, Kovacs P, et al. Retinol binding protein $4(\mathrm{RBP} 4)$ is primarily associated with adipose tissue mass in children. Int $\mathrm{J}$ Pediatr Obes. 2011;6:e345-52. doi: 10.3109/17477166.2010.491228

8. Wolf G. Serum retinol-binding protein: a link between obesity, insulin resistance, and type 2 diabetes. Nutr Rev. 2007;65(5): 251-6. PMID: 17566551

9. Zabetian-Targhi F, Mahmoudi MJ, Rezaei N, Mahmoudi M. Retinol binding protein 4 in relation to diet, inflammation, immunity, and cardiovascular diseases. Adv Nutr. 2015;6:748-62. doi: 10.3945/an.115.008292

10. Kadoglou NPE, Lambadiari V, Gastounioti A, Gkekas C, Giannakopoulos TG, Koulia K, et al. The relationship of novel adipokines, RBP4 and omentin-1, with carotid atherosclerosis severity and vulnerability. Atherosclerosis. 2014;235(2):606-12. doi: 10.1016/j.atherosclerosis.2014.05.957

11. Li F, Xia K, Sheikh MS, Cheng J, Li C, Yang T. Retinol binding protein 4 promotes hyperinsulinism induced proliferation of rat aortic smooth muscle cells. J Mol Med Rep. 2014;9(5): 1634-40. doi: 10.3892/mmr.2014.2028

12. Herouvi D, Karanasios E, Karayianni C, Karavanaki K. Cardiovascular disease in childhood: the role of obesity. Eur J Pediatr. 2013;172(6):721-32. doi: 10.1007/s00431-013-1932-8

13. American Diabetes Association. Standards of Medical Care in Diabetes 2013. Diabetes Care. 2013;36(Suppl 1):S11-S66.

14. World Medical Association Declaration of Helsinki: Recommendations guiding physicians in biomedical research involving human subjects. JAMA. 1997;277:925-6. PMID: 9062334

15. World Health Organization (WHO), Growth reference 5-19 years, 2007, http://www.who.int/growthref/who2007_bmi_ for_age/en/.

16. McMahan CA, Gidding SS, Fayad ZA, Zieske AW, Malcom GT, Tracy RE, et al. Risk scores predict atherosclerotic lesions in young people. Arch Intern Med. 2005;165:883-90. doi: 10.1001/archinte.165.8.883

17. Klisic A, Kavaric N, Soldatovic I, Bjelakovic B, Kotur-Stevuljevic J. Relationship between cardiovascular risk score and traditional and nontraditional cardiometabolic parameters in obese adolescent girls. J Med Biochem. 2016;35(3):282-92. doi: 10.1515/jomb-2016-0005

18. Zimmet P, Alberti KGMM, Kaufman F, Tajima N, Silink M, et al. The metabolic syndrome in children and adolescents - an IDF consensus report. Pediatr Diabetes. 2007:8;299-306. doi: 10.1111/j.1399-5448.2007.00271.x

19. Matthews DR, Hosker JP, Rudenski AS, Naylor BA, Treacher DF, Turner RC. Homeostasis model assessment: insulin resistance and $\beta$-cell function from fasting plasma glucose and insulin concentrations in man. Diabetologia. 1985;28:412-9. PMID: 3899825

20. Bugge A, El-Naaman B, McMurray RG, Froberg K, Andersen LB. Tracking of clustered cardiovascular disease risk factors 
from childhood to adolescence. Pediatr Res. 2013;73:245-9. doi: 10.1038/pr.2012.158

21. Feng S, Zhu Y, Yan C, Wang Y, Zhang Z. Retinol binding protein 4 correlates with and is an early predictor of carotid atherosclerosis in type 2 diabetes mellitus patients. J Biomed Res. 2015;29(6):451-5. doi: 10.7555/JBR.29.20140087

22. Liu Y, Wang D, Li D, Sun R, Xia M. Associations of retinolbinding protein 4 with oxidative stress, inflammatory markers, and metabolic syndrome in a middle-aged and elderly Chinese population. Diabetol Metab Syndr. 2014;6:25. doi: 10.1186/ 1758-5996-6-25

23. Choi KM, Yannakoulia M, Park MS, Cho GJ, Kim JH, Lee $\mathrm{SH}$, et al. Serum adipocyte fatty acid-binding protein, retinolbinding protein 4 , and adiponectin concentrations in relation to the development of the metabolic syndrome in Korean boys: a 3-y prospective cohort study. Am J Clin Nutr. 2011;9:19-26. doi: 10.3945/ajen.2010.29667

24. Lin CJ, Chu NF, Hung YJ, Chang JB, He CT, Hsiao FC, et al. The association of retinol-binding protein 4 with metabolic syndrome and obesity in adolescents. The effects of gender and sex hormones. Clin Pediatr. 2013;52(1):16-23. doi: 10.1177/ 0009922812459948.

25. Saki F, Ashkani-Esfahani S, Karamizadeh Z. Investigation of the relationship between retinol binding protein 4 , metabolic syndrome and insulin resistance in Iranian obese 5-17 year old children. Iran J Pediatr. 2013;23(4):396-402. PMCID: PMC3883368
26. Reinehr T, Stoffel-Wagner B, Roth CL. Retinol-binding protein 4 and its relation to insulin resistance in obese children before and after weight loss. J Clin Endocrinol Metab. 2008;93:2287-93. doi: 10.1210/jc.2007-2745

27. Goodman E, Graham TE, Dolan LM, Daniels SR, Goodman ER, Kahn BB. The relationship of retinol binding protein 4 to changes in insulin resistance and cardiometabolic risk in overweight black adolescents. J Pediatr. 2009;154:67-73. doi: 10.1016/j.jpeds.2008.07.018

28. Faries PL, Rohan DI, Wyers MC, Marin ML, Hollier LH, Quist WC, LoGerfo FW. Vascular smooth muscle cells derived from atherosclerotic human arteries exhibit greater adhesion, migration, and proliferation than venous cells. J Surg Res. 2002;104:22-8. doi: 10.1006/jsre.2002.6399

29. Alkharfy KM, Al-Daghri NM, Vanhoutte PM, Krishnaswamy $\mathrm{S}, \mathrm{Xu} \mathrm{A}$. Serum retinol-binding protein 4 as a marker for cardiovascular disease in women. PLoS One. 2012;7:e48612. doi: 10.1371/journal.pone.0048612

30. Mahmoudi MJ, Mahmoudi M, Siassi F, Hedayat M, Pasalar P, Chamari M, et al. Circulating retinol-binding protein 4 concentrations in patients with coronary artery disease and patients with type 2 diabetes mellitus. Int J Diabetes Dev Ctries. 2012;32:105-10. doi:10.1007/s13410-012-0077-z

31. Mallat Z, Simon T, Benessiano J, Clement K, Taleb S, Wareham NJ, et al. Retinol-binding protein 4 and prediction of incident coronary events in healthy men and women. J Clin Endocrinol Metab. 2009;94:255-60. doi: 10.1210/jc.2008-0253

\title{
Sažetak

\begin{abstract}
POVEZANOST RETINOL-VEZUJUĆEG PROTEINA 4 I KARDIOVASKULARNOG RIZIKA POSREDOVANA JE OBIMOM STRUKA KOD PRETILIH/DEBELIH ADOLESCENTICA
\end{abstract}

\author{
A. Klisić, N. Kavarić, B. Bjelaković, I. Soldatović, M. Martinović i J. Kotur-Stevuljević
}

Retinol-vezujući protein 4 (RBP4) je novi čimbenik rizika za aterosklerotsku bolest kod odraslih. Međutim, prema našem saznanju nema studija koje su ispitivale povezanost između RBP4 i kardiovaskularnog rizika u mlađoj populaciji. Zato je cilj naše studije bio ispitati ovu moguću povezanost kod pretilih/debelih adolescentica. U istraživanju je sudjelovalo ukupno 70 pretilih/debelih adolescentica u dobi od 17,6 $\pm 1,20$ godina. Mjereni su antropometrijski i biokemijski parametri. Zbir kardiovaskularnog rizika (engl. cardiovascular risk score, CVRS) računao se dodavanjem bodova za svaki pojedinačni čimbenik rizika (npr. spol, HDL-c ne-HDL-c, pušenje, krvni tlak i glikemija natašte). Prema stupnju kardiovaskularnog rizika adolescentice smo podijelili u tri skupine s niskim, srednjim i većim rizikom $(-2 \leq \mathrm{CVRS} \leq 1,2 \leq \mathrm{CVRS} \leq 4$, i $C V R S \geq 5)$. Uočili smo statistički značajno višu razinu RBP4 u skupini s većim rizikom u usporedbi sa skupinom s niskim rizikom $(\mathrm{p}<0,001)$. Međutim, primjenom multiple regresijske analize uočili smo da je obim struka (beta=0,257, $p=0,031$ ) jedini nezavisni predskazatelj većeg kardiovaskularnog rizika $\left(\mathrm{R}^{2}=0,342, \mathrm{p}<0,001\right)$. U zaključku, $\mathrm{RBP} 4$ može biti povezan $\mathrm{s}$ većim kardiovaskularnim rizikom kod pretilih/debelih adolescentica, ali je ova povezanost posredovana abdominalnom pretilošću.

Ključne riječi: Adolescenti; Kardiovaskularne bolesti; Rizik; Pretilost; Retinol-vezujući protein 4 